\title{
Comparison of solid media for cultivation of anaerobes
}

\author{
M Heginbothom, T C Fitzgerald, W G Wade
}

\begin{abstract}
Two commercial agar media for the cultivation of anaerobes were compared with four other media for their ability to support the growth of a wide range of anaerobes from clinical specimens of subgingival plaque. Fastidious anaerobe agar (FAA, Lab $M$ ) and anaerobe agar (GAA, Gibco) allowed better growth of the pure cultures than the other media. FAA recovered the highest numbers of bacteria from subgingival plaque specimens which were composed predominantly of anaerobes. GAA performed poorly with these samples. It is concluded that FAA seemed to be superior to the other media tested for the cultivation and recovery of anaerobes.
\end{abstract}

The importance of obligately anaerobic bacteria in infection is increasingly being recognised. Isolation techniques have improved with the widespread introduction of anaerobic cabinets and the use of transport media. Nutritionally rich culture media, designed specifically for the cultivation of anaerobes, have also become available. The evaluation of new media for anaerobes, however, is difficult in the clinical laboratory. The numbers and range of anaerobes in clinical specimens may have been depleted by poor collection techniques or inadequate or delayed transport before receipt in the laboratory, or both. Differences among media may therefore go undetected. Pure cultures of standard strains for culture collections can also be used to evaluate media. While this may be useful for the detection of nutritional deficiencies of media for particular groups of organisms, standard strains, having been subcultured several times and survived to be catalogues, are more adaptable than fresh isolates.

In advanced periodontal disease the microflora of deep periodontal pockets is composed predominantly of obligate anaerobes, ${ }^{1}$ and up to 325 species may be represented. ${ }^{2}$ Therefore, subgingival plaque makes an excellent source of clinical material for the evaluation of new culture media for anaerobes.

In this study two media designed specifically for the cultivation of anaerobes were compared with four other media for their ability to allow the growth of standard strains and freshly isolated of anaerobes and to recover anaerobes from subgingival plaque.

\section{Methods}

The following standard strains were used: Actinomyces viscosus NCTC 10951, Actinomyces odontolyticus NCTC 9935, Bacteroides intermedius NCTC 9936, Fusobacterium nucleatum NCTC 10562, Peptostreptococcus anaerobius NCTC 11460, Peptostreptococcus asaccharolyticus NCTC 11461 and Wolinella recta NCTC 11459.

The fresh isolates tested were recovered from subgingival plaque from periodontal pockets more than $6 \mathrm{~mm}$ in depth in patients with chronic periodontitis and identified using schemes contained in the Manual of Clinical Microbiology. ${ }^{3}$ Strains used were as follows: Bacteroides intermedius $(\mathrm{n}=2)$, Bacteroides veroralis $(n=1)$, Bacteroides oralis $(n=1)$, Fusobacterium nucleatum $(\mathrm{n}=5)$, Fusobacterium varium $(\mathrm{n}=1)$, Fusobacterium alocis/ sulci $(\mathrm{n}=2), \quad$ Porphyromonas gingivalis $(\mathrm{n}=4)$, Wolinella spp $(\mathrm{n}=2)$, Selenomonas sputigena $(\mathrm{n}=1)$, Veillonella parvula $(\mathrm{n}=2)$, Actinomyces israelii $(\mathrm{n}=3)$, Actinomyces vis$\operatorname{cosus}(\mathrm{n}=1)$, Propionibacterium acnes $(\mathrm{n}=3)$, Eubacterium aerofaciens $(\mathrm{n}=1)$, Eubacterium alactolyticum $(\mathrm{n}=2), \quad$ Peptostreptococcus micros $(n=4)$, and Peptostreptococcus anaerobius $(\mathrm{n}=2)$.

The media tested were as follows: fastidious anaerobe agar (FAA, Lab M, Bury, England), anerobe agar (GAA, Gibco, Paisley, Scotland), Columbia agar (Oxoid, Basingstoke, England), Columbia agar with $0.5^{\circ}$ o yeast extract (Difco, West Molesey, England), and $5 \mathrm{mg} / 1$ haemin and $10 \mathrm{mg} / \mathrm{l}$ vitamin $\mathrm{K}$ (E Col) brain heart infusion agar (Oxoid) and Wilkins Chalgren agar (Difco). All media were supplemented with $5^{\circ} \%$ defibrinated horse blood (Tissue Culture Services, Buckinghamshire, England).

Organisms were grown for 48 hours anaerobically on Columbia agar with $5 \%$ defibrinated horse blood and then harvested into Ringer's solution and the turbidity adjusted to the McFarland No 1 standard. Suspension $(10 \mu \mathrm{l})$ was inoculated on to a whole plate of each test medium and regressively spread. Plates were incubated for five days at $37^{\circ} \mathrm{C}$ in an anaerobic cabinet (Don Whitley MR III, Don Whitley Scientific, Shipley, England) and examined daily for growth. Growth was scored as follows: $-=$ no growth, $+=$ poor growth, $++=$ moderate growth, $+++=$ good growth.

Thirty samples of subgingival plaque were obtained from periodontal pockets more than $6 \mathrm{~mm}$ in depth from patients with chronic 


\begin{tabular}{|c|c|c|c|c|c|c|c|c|c|c|c|c|}
\hline & \multicolumn{6}{|c|}{48 hours } & \multicolumn{6}{|c|}{120 hours } \\
\hline & $W C$ & Col & E Col & $B H I$ & $F A A$ & $G A A$ & $W C$ & Col & $E$ Col & $B H I$ & $F A A$ & $G A A$ \\
\hline $\begin{array}{l}A \text { viscosus } 10951 \\
A \text { odontolyticus } 9935 \\
B \text { intermedius } 9336 \\
F \text { nucleatum } 10562 \\
P \text { asaccharolyticus } 11461 \\
P \text { anaerobius } 11460 \\
W \text { recta } 11459\end{array}$ & $\begin{array}{l}+++ \\
+++ \\
++ \\
+++ \\
++ \\
++ \\
+++\end{array}$ & $\begin{array}{l}+++ \\
+++ \\
+++ \\
+++ \\
+++ \\
+++ \\
++\end{array}$ & $\begin{array}{l}++ \\
+++ \\
+++ \\
+++ \\
+++ \\
+++ \\
+++\end{array}$ & $\begin{array}{l}++ \\
+++ \\
++ \\
+++ \\
+++ \\
+++ \\
+++\end{array}$ & $\begin{array}{l}+++ \\
+++ \\
+++ \\
+++ \\
+++ \\
+++ \\
+++\end{array}$ & $\begin{array}{l}++ \\
+++ \\
+++ \\
+++ \\
+++ \\
+++ \\
+++\end{array}$ & $\begin{array}{l}+++ \\
+++ \\
+++ \\
+++ \\
+++ \\
+++ \\
+++\end{array}$ & $\begin{array}{l}+++ \\
+++ \\
+++ \\
+++ \\
+++ \\
+++ \\
+++\end{array}$ & $\begin{array}{l}+++ \\
+++ \\
+++ \\
+++ \\
+++ \\
+++ \\
+++\end{array}$ & $\begin{array}{l}+++ \\
+++ \\
+++ \\
+++ \\
+++ \\
+++ \\
+++\end{array}$ & $\begin{array}{l}+++ \\
+++ \\
+++ \\
+++ \\
+++ \\
+++ \\
+++\end{array}$ & $\begin{array}{l}+++ \\
+++ \\
+++ \\
+++ \\
+++ \\
+++ \\
+++\end{array}$ \\
\hline
\end{tabular}

WC-Wilkins Chalgren agar; BHI-Brain heart infusion agar; Col-Columbia agar; FAA-Fastidious anaerobe agar; E Col-Enriched Columbia agar; GAA-

Gibco anaerobe agar.
$-=$ no growth; $+=$ poor growth $;+=$ moderate growth; $+++=$ good growth.

periodontitis. Samples were taken using a small spoon excavator, immersed in $2 \mathrm{ml}$ reduced transport medium ${ }^{4}$ and taken immediately to the laboratory. Samples were dispersed by vortex mixing for 30 seconds after the addition of $0.25 \mathrm{ml}$ mesh glass beads (BDH, Poole, England). The test media were inoculated using a spiral plater (Spiral Systems, Don Whitley Scientific) and incubated for seven days in the anaerobic cabinet. An extra Columbia agar plate was incubated in air $+10 \%$ carbon dioxide. After incubation the plates were counted and the results expressed as colony forming units (cfu)/specimen and anaerobe count: air + carbon dioxide count.

The counts obtained from the clinical specimens were compared using paired $t$ tests and Wilcoxon paired tests on log-transformed data. Two-way analysis of variance was performed on the untransformed data.

\section{Results}

GROWTH OF PURE CULTURES

The results of growth of standard strains at 48 and 120 hours is shown in table 1 . No differences were detected among media; all strains grew moderately by 48 hours and good growth was seen by 120 hours. In contrast, differences were seen among media in the growth of the fresh isolates of $F$ nucleatum, $P$ gingivalis, $A$ israelii, $E$ aerofaciens, $E$ alactolyticum and $P$ anaerobius (table 2). The $F$ nucleatum strains showed moderate or good growth on FAA and GAA at 48 hours but only poor or moderate growth on the other media. Growth of all four $P$ gingivalis strains could only be detected on brain heart infusion agar at 48 hours while no strains gave detectable growth on Wilkins Chalgren agar or Columbia agar at that time. At 120 hours good growth of all strains was seen on $\mathrm{E} \mathrm{Col,} \mathrm{brain}$ heart infusion agar, FAA and GAA. GAA permitted good growth of all $P$ acnes strains at 48 hours while strain 1305 was undetectable on the other media at this time. By 120 hours good growth of all strains was seen only on FAA and GAA. The Eubacterium species tested exhibited similar results, good growth at 120 hours being confined to FAA and GAA. $P$

Table 2 Growth of fresh isolates on six media

\begin{tabular}{|c|c|c|c|c|c|c|c|c|c|c|c|c|c|}
\hline \multirow[b]{2}{*}{ Species } & \multirow{2}{*}{$\begin{array}{l}\text { Isolate } \\
\text { No }\end{array}$} & \multicolumn{6}{|c|}{48 hours } & \multicolumn{6}{|c|}{120 hours } \\
\hline & & $W C$ & Col & E Col & $B H I$ & $F A A$ & $G A A$ & $W C$ & $\mathrm{Col}$ & E Col & $B H I$ & $F A A$ & $G A A$ \\
\hline$B$ intermedius & 1351 & ++ & ++ & ++ & ++ & ++ & ++ & +++ & +++ & +++ & +++ & +++ & +++ \\
\hline \multirow{6}{*}{$\begin{array}{l}B \text { veroralis } \\
B \text { oralis } \\
F \text { nucleatum }\end{array}$} & 2002 & \pm & $\begin{array}{l}+ \\
-\end{array}$ & \pm & $\begin{array}{l}++ \\
-\end{array}$ & $\begin{array}{l}+++ \\
+\end{array}$ & ++ & +++ & +++ & +++ & $++t$ & +++ & +++ \\
\hline & 1379 & $\bar{t}+$ & $\bar{t}++$ & $\bar{t}+$ & $\bar{t}+$ & & & $\begin{array}{l}++ \\
++t\end{array}$ & +++ & +++ & +++ & ++ & $++t$ \\
\hline & $\begin{array}{r}2003 \\
574\end{array}$ & $\begin{array}{l}++ \\
+\end{array}$ & + & + & + & $\begin{array}{l}+++ \\
+++\end{array}$ & $\begin{array}{l}++ \\
+++\end{array}$ & $\begin{array}{l}+++ \\
++\end{array}$ & $\begin{array}{l}+++ \\
++\end{array}$ & $\begin{array}{l}+++ \\
++\end{array}$ & $\begin{array}{l}+++ \\
++\end{array}$ & $\begin{array}{l}+++ \\
+++\end{array}$ & $\begin{array}{l}+++ \\
+++\end{array}$ \\
\hline & $\begin{array}{r}2004 \\
585\end{array}$ & $\begin{array}{l}++ \\
+\end{array}$ & $\begin{array}{l}++ \\
+\end{array}$ & & $\begin{array}{l}++ \\
+\end{array}$ & $\begin{array}{l}+++ \\
++\end{array}$ & $\begin{array}{l}+++ \\
++\end{array}$ & $\begin{array}{l}+++ \\
++\end{array}$ & $\begin{array}{l}+++ \\
++\end{array}$ & $\begin{array}{l}+++ \\
++\end{array}$ & $\begin{array}{l}+++ \\
+++\end{array}$ & $\begin{array}{l}+++ \\
+++\end{array}$ & $\begin{array}{l}+++ \\
+++\end{array}$ \\
\hline & 2005 & ++ & ++ & + & ++ & +++ & +++ & +++ & +++ & +++ & +++ & +++ & +++ \\
\hline & 639 & + & + & ++ & + & +++ & +++ & +++ & +++ & +++ & +++ & +++ & $\begin{array}{l}++ \\
++t\end{array}$ \\
\hline \multirow{2}{*}{$\begin{array}{l}\text { F varium } \\
\text { Fusobacterium spp }\end{array}$} & 1369 & ++ & + & + & ++ & ++ & ++ & $++t$ & +++ & +++ & $\begin{array}{l}+++ \\
++t\end{array}$ & $\begin{array}{l}+++ \\
+++\end{array}$ & $\begin{array}{l}+++ \\
+++\end{array}$ \\
\hline & $\begin{array}{l}1359 \\
1358\end{array}$ & + & + & + & $\begin{array}{l}+ \\
++\end{array}$ & $\begin{array}{l}+ \\
++\end{array}$ & $\begin{array}{l}++ \\
+++\end{array}$ & $\begin{array}{l}+++ \\
++t\end{array}$ & $\begin{array}{l}+++ \\
+++\end{array}$ & $\begin{array}{l}+++ \\
+++\end{array}$ & $\begin{array}{l}+++ \\
+++\end{array}$ & +++ & +++ \\
\hline \multirow[t]{3}{*}{ Pgingivalis } & 641 & - & $\begin{array}{l}\mathrm{T} \\
-\end{array}$ & + & + & + & + & ++ & ++ & ++ & +++ & +++ & $++t$ \\
\hline & 1360 & - & - & + & + & - & \pm & $\begin{array}{l}++ \\
+\end{array}$ & + & $\begin{array}{l}+++ \\
++t\end{array}$ & $\begin{array}{l}+++ \\
+++\end{array}$ & $\begin{array}{l}+++ \\
+++\end{array}$ & $\begin{array}{l}++t \\
++t\end{array}$ \\
\hline & 576 & $\overline{-}$ & - & - & $\begin{array}{l}+ \\
+\end{array}$ & $\overline{-}$ & $\overline{-}$ & $\stackrel{t}{+}+$ & $\begin{array}{l}+ \\
+\end{array}$ & $\begin{array}{l}+++ \\
+++\end{array}$ & +++ & +++ & $++t$ \\
\hline Wolinella spp & $\begin{array}{l}2001 \\
2009\end{array}$ & $\overline{+}+$ & +++ & +++ & + & +++ & $++t$ & $++t$ & $\begin{array}{l}++t \\
++t\end{array}$ & $\begin{array}{l}+++ \\
+++\end{array}$ & $\begin{array}{l}+++ \\
+++\end{array}$ & $\begin{array}{l}+++ \\
+++\end{array}$ & $\begin{array}{l}+++ \\
+++\end{array}$ \\
\hline & $\begin{array}{l}663 \\
450\end{array}$ & ++ & $\stackrel{+}{-}$ & & $\begin{array}{l}++ \\
++\end{array}$ & $\begin{array}{l}+++ \\
+\end{array}$ & $\begin{array}{l}+++ \\
+\end{array}$ & $\begin{array}{l}+++ \\
+++\end{array}$ & +++ & +++ & +++ & +++ & +++ \\
\hline $\begin{array}{l}S \text { sputigena } \\
V \text { parvula }\end{array}$ & $\begin{array}{l}450 \\
500\end{array}$ & +++ & ++ & +++ & +++ & +++ & +++ & $++t$ & +++ & +++ & +++ & $\begin{array}{l}+++ \\
++t\end{array}$ & $\begin{array}{l}+++ \\
+++\end{array}$ \\
\hline paroula & 447 & +++ & ++ & ++ & $\begin{array}{l}++ \\
+\end{array}$ & $\begin{array}{l}+++ \\
+\end{array}$ & $\begin{array}{l}++ \\
+\end{array}$ & $\begin{array}{l}+++ \\
+++\end{array}$ & $\begin{array}{l}+++ \\
++\end{array}$ & $\begin{array}{l}+++ \\
++\end{array}$ & $\begin{array}{l}+++ \\
++\end{array}$ & $\begin{array}{l}+++ \\
+++\end{array}$ & +++ \\
\hline \multirow[t]{2}{*}{ A israelii } & $\begin{array}{l}658 \\
647\end{array}$ & $\begin{array}{l}+ \\
+\end{array}$ & $\stackrel{+}{-}$ & $\begin{array}{l}+ \\
+\end{array}$ & $\begin{array}{l}+ \\
-\end{array}$ & $\stackrel{+}{-}$ & - & $\begin{array}{l}+++ \\
++\end{array}$ & ++ & ++ & +++ & +++ & +++ \\
\hline & 2006 & + & ++ & ++ & ++ & ++ & ++ & ++ & ++ & ++ & +++ & +++ & $\begin{array}{l}+++ \\
+++\end{array}$ \\
\hline \multirow{3}{*}{$\begin{array}{l}A \text { viscosus } \\
P \text { acnes }\end{array}$} & 2007 & ++ & ++ & + & $\stackrel{+}{+}$ & \pm++ & $\begin{array}{l}+++ \\
+++\end{array}$ & $\begin{array}{l}+++ \\
+\end{array}$ & $\begin{array}{l}+++ \\
++\end{array}$ & $\begin{array}{l}+++ \\
+\end{array}$ & $\begin{array}{l}+++ \\
+\end{array}$ & $\begin{array}{l}+++ \\
+++\end{array}$ & +++ \\
\hline & 1305 & $\overline{+}+$ & $\bar{t}$ & $\bar{t}$ & ++ & + & +++ & ++ & ++ & +++ & +++ & ++ & ++ \\
\hline & 1392 & ++ & ++ & ++ & ++ & +++ & +++ & +++ & $++t$ & $\begin{array}{l}+++ \\
++\end{array}$ & $\begin{array}{l}+++ \\
++\end{array}$ & +++ & $\begin{array}{l}+++ \\
+++\end{array}$ \\
\hline \multirow{3}{*}{$\begin{array}{l}E \text { aerofaciens } \\
E \text { alactolyticum }\end{array}$} & 1376 & - & - & - & - & & & & & $\begin{array}{l}++ \\
++\end{array}$ & $\begin{array}{l}++ \\
++\end{array}$ & $\begin{array}{l}++ \\
+++\end{array}$ & $\begin{array}{l}+++ \\
+++\end{array}$ \\
\hline & 1337 & + & + & + & + & + & + & $\begin{array}{l}++ \\
++\end{array}$ & $\begin{array}{l}++ \\
++\end{array}$ & $\begin{array}{l}++ \\
++\end{array}$ & ++ & +++ & +++ \\
\hline & 617 & + & + & + & + & $\begin{array}{l}++ \\
++\end{array}$ & $\begin{array}{l}++ \\
++\end{array}$ & $\begin{array}{l}++ \\
+++\end{array}$ & $\begin{array}{l}++ \\
+++\end{array}$ & +++ & +++ & +++ & +++ \\
\hline \multirow[t]{3}{*}{$P$ micros } & 1345 & + & ++ & + & + & $\begin{array}{l}++ \\
+++\end{array}$ & $\begin{array}{l}++ \\
++\end{array}$ & +++ & +++ & +++ & +++ & +++ & +++ \\
\hline & 1348 & $\begin{array}{l}++ \\
++\end{array}$ & $\begin{array}{l}++ \\
++\end{array}$ & $\begin{array}{l}++ \\
++\end{array}$ & $\begin{array}{l}+t \\
t+\end{array}$ & $\begin{array}{l}+++ \\
++\end{array}$ & ++ & +++ & +++ & +++ & +++ & +++ & +++ \\
\hline & $\begin{array}{l}2011 \\
2012\end{array}$ & $\begin{array}{l}++ \\
++\end{array}$ & $\begin{array}{l}++ \\
++\end{array}$ & $\begin{array}{l}++ \\
++\end{array}$ & ++ & ++ & ++ & $++t$ & +++ & +++ & +++ & $++t$ & $\begin{array}{l}++t \\
+t+\end{array}$ \\
\hline \multirow{2}{*}{$P$ anaerobius } & 794 & - & - & - & - & + & ++ & $\begin{array}{l}++ \\
++\end{array}$ & $\begin{array}{l}+ \\
++\end{array}$ & + & $\begin{array}{l}++ \\
+++\end{array}$ & $\begin{array}{l}+++ \\
+++\end{array}$ & +++ \\
\hline & 580 & - & - & - & $t$ & + & ++ & & r & & & & \\
\hline
\end{tabular}

WC_Wilkins Chalgren agar; BHI-Brain heart infusion agar; Col-Columbia agar; FAA-Fastidious anaerobe agar; E Col-Enriched Columbia agar; GAA- 
Table 3 Recovery of bacteria from subgingival plaque on six media. Total anaerobic count (CFU $\times 10^{4} /$ specimen)

\begin{tabular}{|c|c|c|c|c|c|c|c|c|}
\hline \multirow[b]{2}{*}{ Specimen No } & \multicolumn{7}{|l|}{ Media } & \multirow{2}{*}{$\begin{array}{l}\text { Highest } \\
\text { anaerobic/BA count }\end{array}$} \\
\hline & $W C$ & Col & E Col & $B H I$ & $F A A$ & $G A A$ & $B A^{\star}$ & \\
\hline 1 & 66 & 170 & 99 & - & 67 & 53 & 67 & $2 \cdot 5$ \\
\hline 2 & 170 & 180 & 220 & 120 & 180 & 52 & 29 & $7 \cdot 5$ \\
\hline 3 & 180 & 220 & 190 & 170 & 460 & 140 & 29 & $15 \cdot 8$ \\
\hline 4 & 210 & 210 & 260 & 250 & 320 & 150 & 320 & 1.0 \\
\hline 5 & 73 & 42 & 160 & 120 & 130 & 56 & 30 & $5 \cdot 3$ \\
\hline 6 & $8 \cdot 5$ & 9.9 & 20 & 16 & 22 & 10 & 10 & $2 \cdot 2$ \\
\hline 7 & $2 \cdot 3$ & 1.7 & 1.5 & $1 \cdot 3$ & 1.6 & 1.8 & 0.3 & $7 \cdot 2$ \\
\hline 8 & 310 & 210 & 3.9 & 280 & 260 & 190 & 270 & 1.4 \\
\hline 9 & 46 & 47 & 67 & 65 & 70 & 53 & 89 & 0.8 \\
\hline 10 & 6.7 & 6.9 & $6 \cdot 2$ & $7 \cdot 8$ & $8 \cdot 0$ & 5.8 & 4.5 & 1.8 \\
\hline 11 & 160 & 220 & 390 & 350 & 430 & 190 & 170 & $2 \cdot 5$ \\
\hline 12 & 310 & 340 & 660 & 400 & 1100 & 69 & 14 & $78 \cdot 6$ \\
\hline 13 & 46 & 86 & 140 & 56 & 110 & 25 & $4 \cdot 4$ & 31.8 \\
\hline 14 & 450 & 510 & 440 & 460 & 1000 & 230 & 210 & $4 \cdot 8$ \\
\hline 15 & 50 & 66 & 80 & 69 & 87 & 270 & $2 \cdot 1$ & $128 \cdot 6$ \\
\hline 16 & 370 & 220 & 380 & 310 & 350 & 240 & 240 & $1 \cdot 6$ \\
\hline 17 & 300 & 300 & 500 & 290 & 270 & 200 & 50 & $10 \cdot 0$ \\
\hline 18 & 26 & 39 & 32 & 20 & 89 & 13 & $5 \cdot 4$ & $16 \cdot 5$ \\
\hline 19 & 100 & 99 & 300 & 190 & 310 & 110 & 74 & $4 \cdot 2$ \\
\hline 20 & 420 & 410 & 550 & 260 & 590 & 250 & 74 & $7 \cdot 8$ \\
\hline 21 & 270 & 230 & 250 & 210 & 350 & 110 & 1.6 & $218 \cdot 8$ \\
\hline 22 & 510 & 610 & 750 & 450 & 530 & 300 & 72 & $10 \cdot 4$ \\
\hline 23 & 530 & 790 & 1000 & 490 & 1000 & 320 & 170 & 5.9 \\
\hline 24 & 170 & 170 & 130 & 120 & 190 & 100 & $6 \cdot 7$ & 28.4 \\
\hline 25 & 240 & 230 & 280 & 170 & 230 & 80 & 130 & $2 \cdot 2$ \\
\hline 26 & 350 & 260 & 330 & 340 & 430 & 190 & 78 & $5 \cdot 5$ \\
\hline 27 & 530 & 310 & 840 & 370 & 890 & 330 & 58 & $15 \cdot 3$ \\
\hline 28 & 720 & 62 & 70 & 58 & 110 & 140 & 9.9 & $14 \cdot 1$ \\
\hline 29 & 170 & 210 & 360 & 180 & 260 & 97 & 62 & 5.8 \\
\hline 30 & 450 & 300 & 540 & 330 & 610 & 180 & 120 & $5 \cdot 1$ \\
\hline
\end{tabular}

^BA: Columbia agar incubated in air $+10^{\circ}{ }_{0}$ carbon dioxide.

anaerobius was detectable only at 48 hours on FAA, GAA, and brain heart infusion agar (one strain), and good growth of both strains at 120 hours occurred on FAA and GAA alone.

\section{SUBGINGIVAL PLAQUE SPECIMENS}

The mean anaerobe:air + carbon dioxide ratio was 21.5 , indicating the high proportion of anaerobes in these specimens (table 3 ). FAA produced the highest anaerobic count from 17 of the 30 specimens, followed by $\mathrm{E} \mathrm{Col} \mathrm{(} \mathrm{n}=$ $10)$, GAA $(\mathrm{n}=2)$, Columbia agar $(\mathrm{n}=1)$, Wilkins Chalgren agar $(n=1)$ and brain heart infusion agar $(\mathrm{n}=0)$. Paired $t$ tests and Wilcoxon tests showed highly significant differences $(p<0.001)$ between log-transformed counts for FAA compared with Wilkins Chalgren agar, Columbia agar, brain heart infusion agar and GAA. No significant difference was seen between FAA and E Col. Two-way analysis of variance confirmed highly significant differences among the media, FAA and $\mathrm{E} \mathrm{Col}$ giving the highest counts and GAA the lowest.

\section{Discussion}

The media chosen for this study were used for the primary isolation of anaerobes with the exception of Wilkins Chalgren agar which was formulated for antimicrobial susceptibility testing of anaerobes. ${ }^{5}$ The poor performance of this medium in supporting the growth of fresh isolates suggests that a more nutritious medium should be proposed for the reference method of susceptibility testing.

This study showed that for the cultivation of pure cultures of anaerobes FAA and GAA were superior to the other media tested, while FAA and $\mathrm{E}$ Col gave the highest recoveries from clinical specimens composed predominantly of anaerobes. FAA has been formulated specifically for the optimal cultivation of anaerobes and contains several ingredients which have been reported to enhance the growth of anaerobes. Starch is included to absorb toxic products ${ }^{6}$ and sodium pyruvate is present to neutralise hydrogen peroxide and as an energy source for Veillonella spp. ${ }^{7}$ The medium also contains arginine which has been reported to stimulate the growth of Eubacterium species and sodium bicarbonate for its buffering properties. ${ }^{8}$ Haemin and vitamin $\mathrm{K}$ are growth factors required by many Bacterioides species ${ }^{9}$ and are included together with the reducing agent cysteine hydrochloride, which has also been shown to stimulate directly the growth of some anaerobes. ${ }^{10}$

The poor performance of GAA in the recovery of organisms from clinical specimens was unexpected because it afforded good growth of all the pure cultures tested. Inspection of the plates after 48 hours' growth, however, showed a pronounced discolouration of the plates. This colour change might have been caused by acid production due to the inclusion in the media of $0.5 \%$ glucose. This observation has been reported previously with GAA. ${ }^{11}$ Facultative organisms present in the sample may have produced acid products which subsequently inhibited the growth of slower growing anaerobes. Lactic acid, in particular, has been shown to be inhibitory to Gram negative anaerobes. ${ }^{12}$

The fresh isolates and subgingival plaque specimens tested in this study had been taken from the mouth and thus, it might be argued, the conclusions reached may not be applicable to the cultivation and recovery of clinically important anaerobes from other body sites. In particular, the range of organisms found in subgingival plaque might differ considerably from those found in clinical specimens. The 
groups of anaerobes found in clinical specimens but not normally found in the mouth-fragilis group Bacteroides and Clostridia spp-are generally less nutritionally demanding, however, than the other groups of anaerobes isolated from man, including those found in the mouth. Therefore the results of this study may have relevance for all body sites. Furthermore, higher isolation rates of anaerobes resulting from the use of improved media may result in the finding of positive associations between previously uncultivated anaerobes and disease states. A recent example is the frequent isolation of Eubacterium nodatum $^{13}$ from infections associated with intrauterine contraceptive devices; $E$ nodatum was originally described as a fastidious periodontal species. ${ }^{14}$ In conclusion, on the basis of the results of this study FAA seems to be a useful all-round medium for the cultivation and recovery of anaerobes.

1 Slots J. Subgingival microflora and periodontal disease. $J$ Clin Peridontol 1979;6:351-82.

2 Moore WEC. Microbiology of periodontal disease. Periodont Res 1987;22:335-41.

3 Lennette H, Balows A, Hausler WJ Jr, Shadomy HJ, eds. Manual of clinical microbiology, 4 th ed. Washington, DC:
American Society for Microbiology, 1985.

4 Bowden GH, Hardie JM. Anaerobic organisms from the human mouth. In: Shapton DA, Board RG, eds. Isolation of anaerobes, London: Academic Press, 1971:177-205.

5 Wilkins TD, Chalgren S. Medum for use in antibiotic susceptibility testing of anaerobic bacteria. Antimicrob Agents Chemother 1976;10:926-8.

6 Ajello GW, Feeley JC, Hayes PS, et al. Trans-isolate medium: a new medium for primary culturing and transport of Neisseria meningitidis, Streptococcus pneumoniae, and Haemophilus influenzae. J Clin Microbiol 1984; iae, and $\mathrm{H}$. $55-8$.

7 Nielsen PA. Role of reduced sulphur compounds in nutrition of Propionibacterium acnes. J Clin Microbiol 1983 17:276-9.

8 Sperry JF, Wilkins TD. Arginine, a growth-limiting facto for Eubacterium lentum. J Bacteriol 1976;127:780-4

9 Gibbons RJ, Macdonald JB. Haemin and vitamin K a required factors for cultivation of certain strains of $B$ melaninogevicus. J Bacteriol 1960;80:164-70.

10 Shanson DC, Singh J. Effect of adding cysteine to brainheart infusion broth on the isolation of Bacteroides fragilis from experimental blood cultures. J Clin Pathol 1981; from experim

11 Watt B, Brown FV. Effect of the growth of anaerobic bacteria on the surface $\mathrm{pH}$ of solid media. J Clin Pathol 1985;38:565-9.

12 Mashimo PA, Yamamoto Y, Nakamura M, Reynolds HS Genco RJ. Lactic acid production by oral Streptococcus mitis inhibits the growth of oral Capnocytophaga. $J$ Periodontol 1985;56:548-52.

13 Hill GB, Ayers OM, Kohan AP. Characteristics and sites of infection of Eubacterium nodatum. Eubacterium timidum, Eubacterium brachy and other asaccharolytic Eubacteria. J Clin Microbiol 1987;25:1540-5.

14 Holdeman LV, Cato EP, Burmeister JA, Moore WEC Descriptions of Eubacterium timidum sp. nov., Eubacterium brachy sp. nov., and Eubacterium nodatum sp. nov. isolated from human periodontitis. Int $J$ Syst Bacteriol 1980;30:163-9. 